\title{
Simbolisme Lempah Kuning Sebagai Daya Tarik Wisata Gastronomi Kabupaten Bangka
}

Agung Ferianda

agung.ferianda@stisipolp12.ac.id

Ferdiana

ferdianave@gmail.com

STISIPOL Pahlawan 12 Sungailiat

\begin{abstract}
ABSTRAK
Lempah kuning tidak hanya sekadar hidangan tapi juga nilai-nilai budaya setempat sehingga dapat dijadikan sebagai daya tarik wisata gastronomi.Memaknai simbol masakan lempah kuning dapat menjadi acuan sebagai sebuah inovasi atau ide baru yang mampu mewujudkan harapan Kabupaten Bangka Provinsi Bangka Belitung untuk menjadikan sektor pariwisata sebagai sektor unggulan pasca-timah.Metode penelitian ini menggunakan perspektif kualitatif dengan pendekatan etnografi/budaya. Teknik pengumpulan data antara lain observasi, wawancara, dan dokumentasi. Teknik analisis data menggunakan teori interaksionisme simbolik. Hasil penelitian bahwa simbolisme lempah kuning sebagai daya tarik wisata gastronomi Kabupaten Bangka antara lain sebagai berikut: (1) lempah kuning adalah simbol kebiasaan kuliner masyarakat Bangka dalam memenuhi kebutuhan fisiologis; (2) lempah kuning sebagai simbol kebersamaan, kekeluargaan pengikat solidaritas masyarakat Bangka karena kebiasaan makan bersama; (3) lempah kuning sebagai simbol identitas kuliner masyarakat kepulauan seperti di Bangka karena penyebutan nama masakan lempah dan masakan lempah kuning merupakan khas Bangka (istilah 'lempah' mengacu pada perilaku konsumsi masyarakat Bangka terhadap hasil perairan baik sungai maupun laut); (4) lempah kuning sebagai simbol pengetahuan masyarakat Bangka dalam memasak ditandai kemampuan pengolahan hasil sumber daya alam sebagai bahan lempah kuning.
\end{abstract}

Kata kunci: simbolisme; lempah kuning; gastronomi; pariwisata

\section{ABSTRACT}

Lempah kuning is a famous culinary from Bangka which is included in the intangible national cultural heritage. Lempah kuning is not only a dish but also local cultural values so that can be used as a gastronomic tourist attraction. Interpreting the symbol of yellow lempah cuisine can be a reference as an innovation or new idea that is able to realize the hopes of Bangka Regency, Bangka Belitung Province to make the tourism sector a leading post-tin sector.This research method used a qualitative perspective with an ethnographic/cultural approach. Data collection techniques include observation, interviews, and documentation. The data analysis technique used the theory of symbolic interactionism. The results of the study showed that the symbolism of the yellow lempah as a gastronomic tourist attraction in Bangka Regency are as follows: (1) yellow lempah is a symbol of the culinary habits of the Bangka people in meeting physiological needs; (2) yellow lempah as a symbol of togetherness, kinship binding the solidarity of the Bangka community because of the habit of eating together; (3) yellow lempah as a symbol of the culinary identity of archipelagic communities such as in Bangka because the mention of the name of the lempah dish and yellow lempah cuisine is typical of Bangka (the term 'lempah' refers to the consumption behavior of the Bangka people towards water products, both rivers and seas); (4) yellow lempah as a symbol of knowledge of the people of Bangka in cooking is marked by the ability to process natural resources as an ingredient of yellow ginger.

Keywords: symbolism; lempah kuning; gastronomy; tourism 


\section{PENDAHULUAN}

Pada tahun 2018 pemerintah daerah Bangka Belitung memutuskan untuk fokus pada program sadar wisata dan sapta pesona.Program tersebut memberdayakan dan membina masyarakat agar berperan penting dalam pembangunan pariwisata, salah satunya menyambut dan menawarkan makanan khas atau kuliner daerah kepada wisatawan mancanegara.

Salah satu masakan khas di Bangka yang menjadi favorit masyarakat Bangka adalah lempah kuning.Lempah kuning adalah kuliner terkenal Bangka yang masuk warisan budaya nasional tak benda. Lempah kuning berbahan dasar ikan segar seperti kakap merah atau tenggiri dengan kuah bercita rasa asam manis pedas dan berwarna kuning.

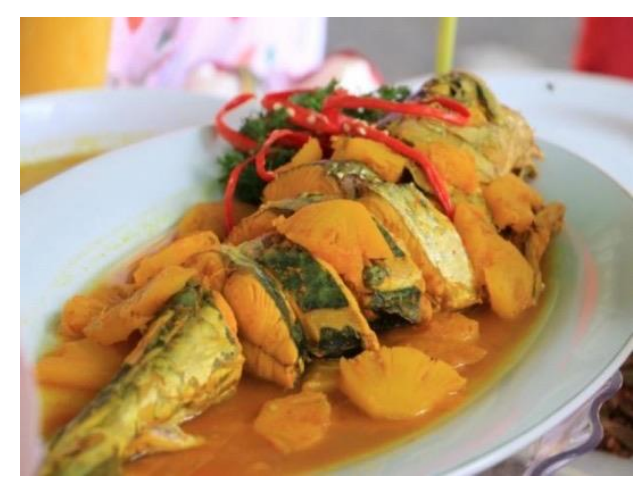

Gambar 1.1 Lempah kuning khas Bangka

Penelitian Desy Misnawati et al. (2019) mengambil judul "Kajian Simbolisme Kuliner Mpek Mpek dalam Interaksi Sosial Masyarakat Palembang."Hasil penelitian tersebut menyimpulkan bahwa kuliner mpek mpek merupakan habitus yang menyantapnya.Kuliner (makanan) mpek mpek merepresentasikan simbolsimbol nilai hidup, nilai karya, nilai ruang atau waktu, nilai relasi dengan alam, dan nilai relasi dengan sesama.Penelitian juga menggambarkan sebuah kuliner yang memiliki makna simbol yang dapat merepresentasikan nilai-nilai kehidupan masyarakat setempat.Kuliner tidak sekadar hidangan tapi juga ada muatan nilai-nilai budaya setempat sehingga dapat dijadikan sebagai daya tarik wisata gastronomi.Begitu juga halnya dengan lempah kuning sebagai masakan khas Bangka.Jadi, tidak hanya mampu memuaskan perut penikmatnya sebagaimana pepatah "Cinta berawal dari perut naik ke hati." Wisatawan akan merasa tertarik untuk terus mengunjungi sebuah wilayah karena — salah satunya - ada cita rasa yang membuat mereka merindukannya. Inilah fungsi kuliner pada sektor wisata: tidak sekadar sebagai pemuas rasa lapar tapi juga ada emosi berupa keinginan kuat yang membuat seseorang selalu terbayang akan kelezatan sebuah masakan sehingga ingin kembali mengunjungi tempat masakan itu berada.Potensi ini sebenarnya dimiliki Bangka dengan masakan khasnya lempah kuning. Untuk itu diperlukan adanya pengembangan oleh dinas terkait termasuk stakeholders pariwisata dalam upaya mewujudkan potensi lempah kuning sebagai daya tarik wisata gastronomi. Masakan lempah kuning dapat menjadi acuan sebagai inovasi atau ide baru mewujudkan harapan Kabupaten Bangka, yakni menjadikan pariwisata sebagai sector unggulan pasca-timah.Pengertian Komunikasi

Komunikasi adalah proses saling bertukar pesan melalui sinyal dengan tujuan menyampaikan informasi, membujuk bahkan memberikan perintah kepada komunikator dalam konteks sosial berdasarkan interpretasi yang sama. Elemen dalam komunikasi ada enam, yaitu pengirim, pesan, medium/saluran, penerima, konteks hubungan, dan lingkungan sosial (Cutlip, 2009). 
Interaksi Simbolik

Interaksi simbolik berakar dari pemikiran bahwa kenyataan sosial merupakan suatu proses yang dinamis. Orang-orang berinteraksi melalui simbol, yang maknanya dihasilkan dari proses negosiasi yang terus-menerus oleh mereka yang terlibat dengan kepentingan masing-masing. Makna suatu simbol bersifat dinamis dan variatif bergantung pada perkembangan dan kepentingan orang tersebut, yang dibingkai oleh ruang dan waktu.Dalam hal ini manusia diletakkan sebagai pelaku aktif sehingga konsep mengenai diri (self) menjadi penting. Konsep diri yang dikaitkan dengan emosi, nilai, keyakinan, dan kebiasaankebiasaan, serta pertimbangan masa lalu dan masa depan, turut mempengaruhi diri dalam pengambilan peran (Laksmi, 2018).

Konsep teori interaksi simbolik diajukan George Herbert Mead. Interaksi simbolik ada karena ide-ide dasar dalam membentuk makna yang berasal dari pikiran manusia (mind) mengenai diri (self), dan hubungannya di tengah interaksi sosial, dan bertujuan akhir untuk memediasi, serta menginterpretasi makna di tengah masyarakat (society) tempat individu tersebut menetap. Seperti yang dicatat oleh Douglas, makna itu berasal dari interaksi, dan tidak ada cara lain untuk membentuk makna, selain dengan membangun hubungan dengan individu lain melalui interaksi (Siregar, 2016).

Pengertian tiga gagasan dasar dari interaksi simbolik, antara lain sebagai berikut:

1.Pikiran (mind) adalah kemampuan manusia dalam menggunakan simbol atau tanda yang memiliki makna sosial yang sama, yakni setiap orang harus mampu mengembangkan pikiran mereka melalui komunikasi atau interaksi yang dilakukan dengan orang lain.

2.Diri (self) adalah kemampuan menggambarkan diri tiap orang dari penilaian berdasarkan sudut pandang atau opini orang lain, dan teori interaksionisme simbolis merupakan salah satu cabang dalam teori sosiologi yang mengemukakan tentang diri sendiri (the-self) dan dunia luarnya.

3. Masyarakat (society) adalah jaringan hubungan sosial yang dibuat dibangun dan dikonstruksikan oleh tiap orang di tengah lingkungan masyarakat, dan masing-masing orang tersebut terlibat dalam bertingkah laku yang mereka pilih secara aktif dan sukarela sehingga membawa mereka mengambil peran di tengah lingkungan masyarakatnya (Siregar, 2016).

\section{Gastronomi}

Gastronomi merupakan sebuah studi tentang korelasi antara budaya dengan makanan.Adapun yang dipelajari berbagai unsur budaya, dan makanan merupakan objek yang berkaitan dengan budaya tersebut. Kegiatan budidaya dalam pertanian yang menghasilkan warna, aroma, dan citarasa pada makananlah membentuk gastronomi sehingga asal muasal suatu makanan dapat diketahui dari lingkungan bahan baku yang diperoleh (Taqwani, 2012).

Gastronomi adalah semua hal yang berkaitan dengan kenikmatan dari makanan dan minuman.Senada dengan pengertian ini, kuliner sudah menjadi identitas yang melekat pada suatu tujuan atau objek pariwisata karena di dalamnya terdapat refleksi tradisi budaya dan identitas budaya yang menjadi data tarik wisatawan (Rijal et al., 2020).

\section{METODOLOGI}

Metode penelitian ini menggunakan perspektif kualitatif dengan pendekatan etnografi atau budaya.Penelitian ini mengkaji tentang simbolisme lempah kuning sebagai daya tarik wisata gastronomi Kabupaten Bangka Provinsi Bangka Belitung.Sifat pemaknaan penelitian ini adalah mengenai kuliner 
LEMPAH KUNING SEBAGAI DAYA TARIK WISATA GASTRONOMI KABUPATEN BANGKA

lempah kuning dalam masyarakat Bangka. Teknik

pengumpulan data antara lain observasi, wawancara, dan dokumentasi. Teknik analisis data menggunakan teori interaksionisme simbolik.

\section{HASIL DAN PEMBAHASAN}

Simbol Kebiasaan Kuliner masyarakat Bangka

Lempah kuning adalah simbol kebiasaan yang dilakukan masyarakat Bangka dalam memenuhi kebutuhan fisiologis.Masing-masing kelompok masyarakat mempunyai pola makan (food pattern) yang umum. Kebiasaan makan (food habit) sebagai kebiasaan suatu kelompok menjadi gambaran cara suatu kebudayaan untuk menetapkan standar perilaku individu dalam kelompok dalam hubungan dengan makanan (Misnawati et al., 2019).

Mengenai lempah kuning sebagai simbol kebiasaan kuliner masyarakat Bangka, budayawan setempat, Sukardi, berkata, "Lempah kuning itu sudah ada sejak zaman nenek moyang kita dan diwariskan secara turun temurun.Jadi, hampir seluruh masyarakat Bangka ini pasti pernah makan lempah kuning bahkan sering, dan bisa memasak lempah kuning."

Lempah kuning disajikan hampir pada setiap momen bahkan menjadi menu harian. Alhasil, secara turun-temurun cara memasak lempah kuning ini tetap bisa dikuasai berbagai generasi. Hanya saja, sesuai dengan perkembangan waktu, ada modifikasi pada bahan dasar hingga bumbu sebagai bentuk interaksi manusia dengan sesamanya maupun lingkungannya.Makna timbul sebab interaksi antar-manusia yang berasal dari hasil pemaknaan pikiran manusia dan hubungannya dalam masyarakat.Interpretasi pada simbol harus dimengerti bahwa simbol merupakan objek sosial yang timbul dari persetujuan bersama dari orang-orang yang menggunakannya.Orang-orang tersebut memberi makna, menciptakan dan mengubah objek dalam interaksi.Wujud simbol sosial dapat berbentuk bahasa, objek fisik, dan tindakan (Laksmi, 2018).

Simbol Kebersamaan, Kekeluargaan Pengikat Solidaritas Masyarakat Bangka

Lempah kuning tidak hanya hadir menjadi santapan sehari-hari tapi juga pada saat berkumpul dengan keluarga hingga pada saat hari raya keagamaan.

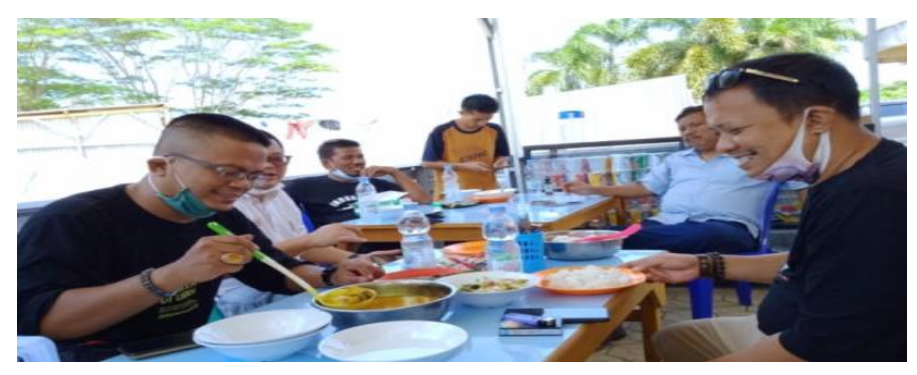

Gambar 3.1 Makan bersama lempah kuning

Kebiasaan menikmati lempah kuning dalam kebersamaan tanpa disadari mengikat solidaritas antar-warga.Pada saat menikmati makan bersama ada aturan yang tetap harus diperhatikan.

Menurut Akhmad Elvian, budayawan dan sejarawan Bangka Belitung, ada aturan budaya tertinggi tentang makan, "Maken same-same (makan bersama), dudok ngelamper (duduk lesehan), nilai budayanya adalah cicik tegem, ambus.Cicik itu kebencian, tegem itu perkelahian atau perselisihan.Ambus itu artinya lenyap.Jadi, bila sudah makan duduk bersama, semua kebencian dan perselisihan, lenyaplah sudah."

Aturan makan paling tinggi di Bangka Belitung adalah makan bersama dalam keadaan lesehan atau tanpa menggunakan kursi atau meja. Ada nilai budaya di dalamnya yang disebut sebagai 'cicik 
LEMPAH KUNING SEBAGAI DAYA TARIK WISATA GASTRONOMI KABUPATEN BANGKA

tegem' yang artinya dengan makan bersama maka akan hilang kebencian dan dihindarkan dari perkelahian. Hal ini dikarenakan selama makan bersama orang-orang saling bersilaturahmi, termasuk pada saat bersama-sama menyantap lempah kuning.

Interaksi yang dilakukan manusia melalui simbol atau tanda memiliki makna-makna tertentu sebagai hasil komunikasi manusia tersebut. Komunikasi yang murni akan terjadi apabila tiap-tiap orang yang berkomunikasi tidak hanya memberi makna pada tindakan mereka sendiri tapi juga paham atau berusaha untuk memahami makna yang disampaikan orang lain (Poloma, 2007).

Dari makna simbolis tersebut, nilai budaya yang dapat disimpulkan adalah kebersamaan, kekeluargaan, dan solidaritas.Durkheim menjelaskan bahwa solidaritas organik suatu masyarakat dibentuk dan dipelihara oleh keberadaan suatu sistem nilai kebersamaan yang secara historis dibangun melalui tradisi (Pratiknjo, 2017).

Simbol Identitas Kuliner Masyarakat Kepulauan

Masakan lempah kuning merupakan khas Bangka. Istilah 'lempah' merujuk pada masakan berkuah yang tidak ditemui di daerah mana pun di Indonesia. Lempah kuning memiliki makna kultural sebagai masakan berkuah yang berbahan ikan dan berkuah kuning akibat pencampuran rempah kunyit.Lempah Kuning menjadi kuliner yang mencerminkan perilaku konsumsi masyarakat Bangka terhadap hasil perairan sungai maupun laut.Kondisi lingkungan memberikan warna dan nuansa jenis makanan baru (Misnawati et al., 2019).

Akhmad Elvian menerangkan bahwa secara etimologi lempah berasal dari kata 'lem' dan 'rempah' sehingga artinya mencampuradukkan bumbu-bumbu yang terdiri dari rempahrempah. Inilah acuan dari asal kata 'lempah'.
Bumbu sederhana yang digunakan bisa didapatkan dari hasil kebun masyarakat Bangka yang terbiasa beuma atau berkebun. Selain itu, ada penambahan berupa terasi, yang merupakan udang rebon fermentasi hasil laut dengan proses cukup panjang. Terasi (shrimp paste) merupakan produk awetan ikanikan kecil atau rebon yang telah diolah melalui proses fermentasi, penggilingan atau penumbukan dan penjemuran (Sharif, 2008).

Identitas masyarakat Bangka sebagai warga kepulauan terlihat jelas dari kemampuan mengolah hasil alam tersebut. Ciri khas makanan sebuah kelompok masyarakat dapat dilihat dari makanan tradisionalnya yang memiliki cita rasa, bentuk, dan cara menikmatinya. Makanan tradisional ini merupakan hasil dari bahan pangan produksi di daerah tersebut dengan teknik mengolah masakan yang telah dikuasai masyarakat setempat (Kristiana et al., 2018).

Simbol Pengetahuan Masyarakat Bangka dalam Memasak

Masakan lempah kuning umumnya memiliki cita rasa asam pedas.Cita rasa asam pedas ini didapat dari penambahan bumbu seperti asam jawa atau belimbing wuluh atau potongan nanas hingga tomat.Pedas berasal dari penambahan bumbu cabai. Menurut Weichart (2004), karakteristik masakan etnis mewakili rasa yang khas dan dikenali dari hasil masakannya.

Cita rasa ini tidak hanya berfungsi sebagai penggugah selera tapi juga untuk mengurangi bau amis ikan, baik ikan sungai maupun ikan laut. Cita rasa asam pedas ini juga bentuk adaptasi masyarakat Bangka karena cuaca setempat. Masalah cita rasa, adaptasi lingkungan, cara mengurangi bau amis pada bahan ikan, dan cara memasak yang benar merupakan gambaran pengetahuan masyarakat Bangka dalam mengolah bahan masakan yang ada sejak dulu.Pengetahuan adalah hasil 'tahu' dan ini terjadi 
setelah orang melakukan pengindraan terhadap suatu

objek tertentu. Pengindraan terjadi melalui pancaindra manusia, yakni indra penglihatan, pendengaran, penciuman, rasa, dan raba (Notoatmodjo, 2012).Pengetahuan masyarakat Bangka dalam memasak bukan dipelajari pada pendidikan formal seperti sekolah tata boga, melainkan hasil belajar dari alam. Sebagaimana dituturkan oleh budayawan Sukardi, "Nenek kita dulu sudah tahu bagaimana menghilangkan bau amis ikan, misalnya ditambahkan bumbu lain seperti serai, bumbunya lebih banyak. Hal ini tidak didapat dari sekolahan seperti kita saat dulu.Itu adalah hasil belajar dari alam."

Pengetahuan masyarakat Bangka pada saat itu dalam memasak merupakan bentuk interaksi dengan alam sehingga kemampuan tersebut dituangkan dalam tindakan seperti memasak. Tidak hanya pada pengolahan bahan lempah kuning, namun juga pada proses pembuatan salah satu penyedapnya, yakni terasi, yang juga memerlukan pengetahuan dalam pengolahannya.

\section{PENUTUP}

Simpulan

$$
\text { Kesimpulan yang disampaikan dalam }
$$
penelitian ini adalah lempah kuning memiliki daya tarik yang kuat sebagai wisata gastronomi Kabupaten Bangka. Simbolisme yang dapat ditonjolkan sebagai daya tarik antara lain: (1) lempah kuning adalah simbol kebiasaan kuliner masyarakat Bangka dalam memenuhi kebutuhan fisiologis; (2) lempah kuning sebagai simbol kebersamaan, kekeluargaan pengikat solidaritas masyarakat Bangka karena kebiasaan makan bersama; (3) lempah kuning sebagai simbol identitas kuliner masyarakat kepulauan seperti di Bangka karena penyebutan nama masakan lempah, dan masakan lempah kuning merupakan khas Bangka (istilah 'lempah' mengacu pada perilaku konsumsi masyarakat Bangka terhadap hasil perairan, baik sungai maupun laut); (4) lempah kuning sebagai simbol pengetahuan masyarakat Bangka dalam memasak, dengan ditandai kemampuan mengolah hasil sumber daya alam sebagai bahan lempah kuning 


\section{DAFTAR PUSTAKA}

Cutlip, Scott M. (2009). Effective Public Relations. Jakarta: Kencana PrenadaMedia Group

Kristiana, Y., Suryadi, M. T., dan Sunarya, S. R. (2018). "Eksplorasi Potensi Wisata Kuliner untuk Pengembangan Pariwisata di Kota Tangerang." Khasanah Ilmu - Jurnal Pariwisata Dan Budaya, 9(1). https://doi.org/10.31294/khi.v9i1.3604

Laksmi, L. (2018). "Teori Interaksionisme Simbolik dalam Kajian Ilmu Perpustakaan dan Informasi." Pustabiblia: Journal of Library and Information Science, 1(2), 121. https://doi.org/10.18326/pustabiblia.v1i2.121138

Misnawati, Desy. (2019). "Kajian Simbolisme Kuliner Mpek Mpek dalam Interaksi Sosial Masyarakat Palembang." Jurnal Vokasi Indonesia, $\quad 7(1), \quad 72-77$. https://doi.org/10.7454/jvi.v7i1.138

Notoatmodjo, Soekidjo. (2012). Pendidikan dan Perilaku Kesehatan. Jakarta: Rineka Cipta

Poloma, Margaret M. (2007). Sosiologi Kontemporer. Jakarta: Raja Grafindo Persada

Pratiknjo, M. H. (2017). "Identitas dan BentukBentuk Budaya Lokal Masyarakat Kabupaten Kepulauan Talaud di Daerah Perbatasan Indonesia-Filipina." Antropologi Indonesia, $37(1)$, 29-39. https://doi.org/10.7454/ai.v37i1.8764
Rijal, S., Fitry, L. D., dan Zaenal, F. A. (2020). "Budaya Gastronomi dalam Pengembangan Desa Wisata di Sulawesi Selatan." Journal of Indonesian History, 9(1), 17-27.

Sharif, R, Ghazali, A.R., Rajab, N.F., HAron, H. \& Osman, F. (2008). "Toxicological Evaluation of Some Malaysian Locally Processed Raw Food Products." Food Chem Toxicol, 46(1):368-

74.https://doi.org/https://doi.org/10.1016/j.fct.20 $\underline{07.08 .010}$

Siregar, Nina S. S. (2016). "Kajian Tentang Interaksionisme Simbolik." Perspektif, 1(2), 100-110.

https://doi.org/10.31289/perspektif.v1i2.86

Taqwani, Dini M. (2012). "Analisis Gastronomi dan Tindak Tutur dalam Kajian Pragmatik pada Film 'Ratatouille'." Skripsi untuk Pendidikan Bahasa Prancis. Bandung: FPBS Universitas Pendidikan Indonesia. Diakses dari http://aresearch.upi.edu/operator/upload/s_jrm_080 8983_chapter1.pdf

Weichart, Gabriele. (2004). "Minahasa Identity: A Culinary Practice." Antropologi Indonesia, No. 74: 55-74. https://doi/org/10.7454/ai.v0i74.3583 